\title{
Influence of Different Fertilizer Systems on Nutrient Status of the Meadow Chestnut Soil and Efficiency of Intercropping of Corn with Soybean
}

\author{
Karlyga Ospanovna Karayeva, Rakhimzhan Yeleshevich Yeleshev \\ and Amangel'dy Kazhiakhmetovich Umbetov
}

Kazakh National Agrarian University, Abay av. 8, 050010 Almaty, Kazakhstan

http://dx.doi.org/10.13005/bbra/2123

(Received: 17 March 2016; accepted: 14 April 2016)

\begin{abstract}
The article presents the results of the research conducted on the irrigated meadow chestnut soil at intercropping of corn with soybean in 2014-2015. Optimal rate and combination of macro- and microfertilizers at intercropping of corn with soybean ensuring positive impact on nutrient and dry matter dynamics have been determined on the piedmont irrigated meadow chestnut soil in southeastern Kazakhstan. Besides, fertilizers influenced corn and soya green mass yield at irrigation.
\end{abstract}

Key words: Yield, dry biomass, micronutrients, corn, soybean, chemical composition, fertilizer.

Fertilizers improve nutrient status of the soil and thus promote plants biomass growth and change of its chemical composition resulting in the increase of nitrogen and phosphorus concentrations both at the initial stage and their full flow to grains at the late stage of growth ${ }^{1}$.

Improvement of mineral nutrition with micronutrients as an integral part is one of the conditions for increasing crop yield. Plants need micronutrients in relatively small quantities. Their lack and excess in the soil results in reduction of yield, quality of agricultural products, and in some cases it causes plants, animals and human diseases $^{2}$.

An increase in yield of the corn and soybean mix, and thus a sufficient increase in production of high quality succulent feed for livestock breeding is a vital task having great national economic significance ${ }^{3}$. So, the research

* To whom all correspondence should be addressed. in mineral nutrition of this crop applying different types and combinations of fertilizers is muchneeded today. Attempts to increase crop yield only by means of NPK fertilizers are sometimes undue because of unbalanced mineral nutrition. In this situation it is necessary to include micronutrients into the fertilizer system and crop cultivation technology ${ }^{4-5}$.

\section{MATERIALSANDMETHODS}

The research was conducted at the scientific-experimental station Agrouniversity of the Kazakh National Agrarian University located in the zone of unstable watering in Enbekshikazakh district, Almaty region. Field trials were performed on the fine-textured meadow chestnut soil typical for the piedmont sasa zone. The meadow chestnut soil of Ile Alatau piedmont plain has dark chestnut colour of the humus horizon, the thickness of which is measured up to $30-40 \mathrm{~cm}$. At that, it is much higher on the irrigated soils comparing to the virgin ones. Soils differ in lack of the distinct Ban horizon. As for the aggregate composition, the meadow 
chestnut soils are characterized by the distinct macrostructure. The topsoil has the following agrochemical characteristics: humus $4.38 \%$, total nitrogen $0.221 \%$, total phosphorus $0.190 \%$, pH 7.8 , labile phosphorus (by Machigin) $22 \mathrm{mg} / \mathrm{kg}$, mineral nitrogen $\left(\mathrm{NO}_{3}\right) 25 \mathrm{mg} / \mathrm{kg}$ and exchange potassium $435 \mathrm{mg} / \mathrm{kg}$ soil.

Variants of field trials with corn and soybean were established in three replications, plots area $56 \mathrm{~m}^{2}$.

Ammonium nitrate $(34 \% \mathrm{~N})$ was used as nitrogen fertilizers, ammophos $\left(46 \% \mathrm{P}_{2} \mathrm{O}_{5}\right)$ - as phosphate fertilizers, potassium chloride $56 \% \mathrm{~K}_{2} \mathrm{O}-$ as potassium fertilizers, and ammonium molybdate (52\% Mo) and zinc sulfate (22\% Zn) - as microfertilizers. Trial arrangement: 1 . Control (without fertilizers), 2. $\mathrm{N}_{60} \mathrm{P}_{60} \mathrm{~K}_{60}, 3 . \mathrm{N}_{60} \mathrm{P}_{60} \mathrm{~K}_{60}+$ $\mathrm{Mo}_{1.5}, 4 . \mathrm{N}_{60} \mathrm{P}_{60} \mathrm{~K}_{60}+\mathrm{Zn}_{2.5}, 5 . \mathrm{N}_{60} \mathrm{P}_{60} \mathrm{~K}_{60}+\mathrm{Mo}_{1.5}+\mathrm{Zn}_{2.5}$, 6. $\mathrm{N}_{120} \mathrm{P}_{120} \mathrm{~K}_{120}, 7 . \mathrm{N}_{120} \mathrm{P}_{120} \mathrm{~K}_{120}+\mathrm{Mo}_{1.5}, 8 . \mathrm{N}_{120} \mathrm{P}_{120} \mathrm{~K}_{120}$ $+\mathrm{Zn}_{2.5}, 9 . \mathrm{N}_{120} \mathrm{P}_{120} \mathrm{~K}_{120}+\mathrm{Mo}_{1.5}+\mathrm{Zn}_{2.5}$.

Before trial establishment we took original soil samples from 0-20, 20-40 cm layers to determine active NPK. Mobile nitrogen $\left(\mathrm{N}-\mathrm{NO}_{3}\right)$ was determined by Grandval-Lyazhu method, labile phosphorus and exchange potassium - in 1\% ammonium carbonate extract by Machigin method.

Plant samples were analyzed to determine the influence of fertilizers under survey on dry biomass accumulation, NP dynamics in plants by vegetation stages. Dry matter accumulation was determined by weight method; nitrogen and phosphorus content in plants was determined in one sample weight after wet combustion by Ginzburg and Shcheglova (nitrogen - by Kjeldahl method, phosphorus - by colorimetric method). Yield was recorded by plots. Yield data were mathematically treated by means of the famous method of B.A. Dospekhov using the Statist program.

\section{RESULTS AND DISCUSSIONS}

Content of nitrate nitrogen in the soil is one of the main parameters characterizing its nitrogen status. In the irrigated soils of southeastern Kazakhstan, nitrates are the key source for nitrogen nutrition of the plants.

Nitrates content in the soil depends on temperature, humidity and state of cultivation of the soil, agricultural technology, and mineral fertilizers applied.

Numerous investigations resulted in establishment of seasonal dynamics of nitrates due to their consumption by plants and change of soil conditions needed for the nitrification process. Nitrates migration at irrigation is also important.

Maximum nitrates content in the meadow chestnut soil was observed in June, and by the end of summer its content was noticeably decreasing. Nitrogen fertilizers had a significant impact on accumulation of nitrates in the soil at intercropping of corn with soybean. Thus, on average within 2 years (2014-2015) content of nitrates in the layer $0-25 \mathrm{~cm}$ at the phase of corn

Table 1. Influence of fertilizers on nitrate nitrogen content in the meadow chestnut soil at intercropping of corn with soybean (average 2014-2015)

\begin{tabular}{lcccccc}
\hline Variants & Layer, & \multicolumn{5}{c}{ Nitrate nitrogen content in the soil, Stage } \\
\cline { 3 - 7 } & cm & Seedling & $\begin{array}{c}\text { 5-6 leaves of } \\
\text { corn and the } \\
\text { third ternate } \\
\text { leaf of soybean }\end{array}$ & $\begin{array}{c}\text { Heading } \\
\text { of panicles } \\
\text { and } \\
\text { blooming }\end{array}$ & $\begin{array}{c}\text { Milky-wax } \\
\text { ripeness of } \\
\text { corn and pod } \\
\text { formation }\end{array}$ & $\begin{array}{c}\text { Average } \\
\text { per season }\end{array}$ \\
\hline 1.Control & & & & & & \\
2. $\mathrm{N}_{60} \mathrm{P}_{60} \mathrm{~K}_{60}$ & $0-20$ & 20.1 & 18.2 & 16.1 & 15.7 & 17.5 \\
3. $\mathrm{N}_{60} \mathrm{P}_{60} \mathrm{~K}_{60}+\mathrm{Mo}_{1.5}$ & $0-20$ & 34.4 & 21.9 & 19.4 & 17.4 & 23.2 \\
4. $\mathrm{N}_{60} \mathrm{P}_{60} \mathrm{~K}_{60}+\mathrm{Zn}_{2.5}$ & $0-20$ & 36.4 & 23.1 & 20.1 & 17.4 & 24.2 \\
5. $\mathrm{N}_{60} \mathrm{P}_{60} \mathrm{~K}_{60}+\mathrm{Mo}_{1.5}+\mathrm{Zn}_{2.5}$ & $0-20$ & 35.5 & 28.9 & 25.8 & 22.4 & 28.1 \\
6. $\mathrm{N}_{120} \mathrm{P}_{120} \mathrm{~K}_{120}$ & $0-20$ & 40.1 & 32.0 & 28.4 & 25.6 & 31.5 \\
7. $\mathrm{N}_{120} \mathrm{P}_{120} \mathrm{~K}_{120}+\mathrm{Mo}_{1.5}$ & $0-20$ & 40.1 & 29.9 & 26.4 & 24.7 & 30.2 \\
8. $\mathrm{N}_{120} \mathrm{P}_{120} \mathrm{~K}_{120}+\mathrm{Zn}_{2.5}$ & $0-20$ & 39.9 & 30.3 & 25.6 & 23.7 & 29.8 \\
9. $\mathrm{N}_{120} \mathrm{P}_{120} \mathrm{~K}_{120}+\mathrm{Mo}_{1.5}+\mathrm{Zn}_{2.5}$ & $0-20$ & 38.4 & 31.0 & 27.3 & 24.1 & 30.2 \\
\hline
\end{tabular}


and soybean seedling on the control variant amounted to $20.1 \mathrm{mg}, 5-6$ leaves of corn and the third ternate leaf of soybean $-18.2 \mathrm{mg}$, heading of panicles and blooming - $16.1 \mathrm{mg}$, milky-wax ripeness of corn and pod formation - $15.7 \mathrm{mg}$ per kg soil; while on variants with NPK fertilizers depending on their norms and combinations with micronutrients nitrate content by phases amounted to: 34.4-46.4 mg; 21.9-40.5 mg and 19.4-35.4 mg per kg soil respectively (Table 1 ).

Ammonium nitrogen is less available for plants than nitrate nitrogen, as $\mathrm{NH}^{+}$is easily taken up by the soil with partial transition to the nonexchangeable state (fixed nitrogen), while $\mathrm{NO}_{3}{ }^{-}$is not taken up by the soil and stays mainly in the soil solution, thus, it is easily used by plants.

As it is known, phosphorus status of plants is mainly determined by the labile phosphorus content in the soil. A number of researchers showed that maximum rate of labile phosphorus at intercropping of corn with soybean is achieved in spring, and by autumn its quantity in the topsoil is gradually decreasing. They report that fertilizers promote sufficient accumulation of labile phosphates in the soil, and nitrogen and its ratio to phosphorus in the soil has a very significant effect on uptake of phosphorus from fertilizers by the plants. It is proved that phosphorus is taken

Table 2. Influence of fertilizers on labile phosphorus content in the meadow chestnut soil at intercropping of corn with soybean (average 2014-2015)

\begin{tabular}{|c|c|c|c|c|c|c|}
\hline \multirow[t]{2}{*}{ Variants } & \multirow{2}{*}{$\begin{array}{l}\text { Layer, } \\
\text { cm }\end{array}$} & \multicolumn{5}{|c|}{ Labile phosphorus content, mg/kg, Stage } \\
\hline & & Seedling & $\begin{array}{l}\text { 5-6 leaves of } \\
\text { corn and the } \\
\text { third ternate } \\
\text { leaf of soybean }\end{array}$ & $\begin{array}{l}\text { Heading } \\
\text { of panicles } \\
\text { and } \\
\text { blooming }\end{array}$ & $\begin{array}{l}\text { Milky-wax } \\
\text { ripeness of } \\
\text { corn and pod } \\
\text { formation }\end{array}$ & $\begin{array}{c}\text { Average } \\
\text { per season }\end{array}$ \\
\hline 1. Control & $0-20$ & 23.0 & 20.9 & 19.8 & 17.5 & 20.3 \\
\hline 2. $\mathrm{N}_{60} \mathrm{P}_{60} \mathrm{~K}_{60}$ & $0-20$ & 25.3 & 24.0 & 22.7 & 19.3 & 22.8 \\
\hline 3. $\mathrm{N}_{60} \mathrm{P}_{60} \mathrm{~K}_{60}^{60}+\mathrm{Mo}_{1.5}$ & $0-20$ & 27.1 & 26.5 & 23.0 & 20.1 & 24.1 \\
\hline 4. $\mathrm{N}_{60} \mathrm{P}_{60} \mathrm{~K}_{60}+\mathrm{Zn}_{2.5}$ & $0-20$ & 25.8 & 23.9 & 21.5 & 21.4 & 23.0 \\
\hline 5. $\mathrm{N}_{60} \mathrm{P}_{60} \mathrm{~K}_{60}+\mathrm{Mo}_{1.5}^{2.5}+\mathrm{Zn}_{2.5}$ & $0-20$ & 30.5 & 26.8 & 25.0 & 21.9 & 26.0 \\
\hline 6. $\mathrm{N}_{120} \mathrm{P}_{120} \mathrm{~K}_{120}$ & $0-20$ & 28.9 & 24.2 & 23.2 & 20.0 & 24.0 \\
\hline 7. $\mathrm{N}_{120}^{120} \mathrm{P}_{120} \mathrm{~K}_{120}^{120}+\mathrm{Mo}_{1.5}$ & $0-20$ & 31.3 & 25.8 & 21.9 & 18.4 & 24.3 \\
\hline 8. $\mathrm{N}_{120} \mathrm{P}_{120} \mathrm{~K}_{120}+\mathrm{Zn}_{2.5}$ & $0-20$ & 30.0 & 26.5 & 22.6 & 19.6 & 24.6 \\
\hline 9. $\mathrm{N}_{120}{ }_{120} \mathrm{P}_{120} \mathrm{~K}_{120}+\mathrm{Mo}_{1.5}+\mathrm{Zn}_{2.5}$ & $0-20$ & 31.6 & 27.0 & 25.9 & 23.4 & 26.9 \\
\hline
\end{tabular}

Table 3. Influence of fertilizers on nutrient content in the corn and soybean plants at intercropping (average 2014-2015)

\begin{tabular}{|c|c|c|c|c|c|c|c|c|}
\hline \multirow[t]{3}{*}{ Variants } & \multicolumn{4}{|c|}{ Corn } & \multicolumn{4}{|c|}{ Soybean } \\
\hline & \multicolumn{2}{|c|}{ Nitrogen,\% } & \multicolumn{2}{|c|}{ Phosphorus,\% } & \multicolumn{2}{|c|}{ Nitrogen,\% } & \multicolumn{2}{|c|}{ Phosphorus, \% } \\
\hline & $\begin{array}{c}5-6 \\
\text { leaves }\end{array}$ & $\begin{array}{l}\text { Milky- } \\
\text { wax } \\
\text { ripeness }\end{array}$ & $\begin{array}{c}5-6 \\
\text { leaves }\end{array}$ & $\begin{array}{l}\text { Milky- } \\
\text { wax } \\
\text { ripenes s }\end{array}$ & $\begin{array}{c}\text { the third } \\
\text { ternate } \\
\text { leaf }\end{array}$ & $\begin{array}{c}\text { pod } \\
\text { forma } \\
\text { tion }\end{array}$ & $\begin{array}{c}\text { the third } \\
\text { ternatee } \\
\text { leaf }\end{array}$ & $\begin{array}{c}\text { pod } \\
\text { forma } \\
\text { tion }\end{array}$ \\
\hline 1. Control & 1.7 & 1.16 & 0.33 & 0.21 & 2.9 & 1.95 & 0.52 & 0.30 \\
\hline 2. $\mathrm{N}_{60} \mathrm{P}_{60} \mathrm{~K}_{60}$ & 3.2 & 1.55 & 0.37 & 0.26 & 3.6 & 2.32 & 0.61 & 0.36 \\
\hline 3. $\mathrm{N}_{60}^{60} \mathrm{P}_{60} \mathrm{~K}_{60}^{60}+\mathrm{Mo}_{15}$ & 2.9 & 1.61 & 0.50 & 0.31 & 3.37 & 2.55 & 0.60 & 0.37 \\
\hline 4. $\mathrm{N}_{60}^{60} \mathrm{P}_{60}^{60} \mathrm{~K}_{60}^{60}+\mathrm{Zn}_{2.5}^{1.5}$ & 2.6 & 1.26 & 0.52 & 0.31 & 3.06 & 2.40 & 0.57 & 0.32 \\
\hline 5. $\mathrm{N}_{60} \mathrm{P}_{60} \mathrm{~K}_{60}+\mathrm{Mo}_{1.5}^{2.3}+\mathrm{Zn}_{2.5}$ & 3.8 & 1.36 & 0.61 & 0.31 & 4.87 & 3.66 & 0.71 & 0.48 \\
\hline 6. $\mathrm{N}_{120}{ }_{120}^{60} \mathrm{P}_{120} \mathrm{~K}_{120}$ & 4.1 & 1.60 & 0.54 & 0.28 & 4.10 & 3.10 & 0.65 & 0.44 \\
\hline 7. $\mathrm{N}_{120} \mathrm{P}_{120}^{120} \mathrm{~K}_{120}+\mathrm{Mo}_{1.5}$ & 4.1 & 1.45 & 0.53 & 0.31 & 4.63 & 3.23 & 0.59 & 0.45 \\
\hline 8. $\mathrm{N}_{120}^{120} \mathrm{P}_{120}^{120} \mathrm{~K}_{120} 20+\mathrm{Zn}_{2.5}^{1.5}$ & 3.4 & 1.50 & 0.59 & 0.32 & 3.91 & 2.44 & 0.61 & 0.39 \\
\hline 9. $\mathrm{N}_{120}{ }^{120} \mathrm{P}_{120}^{120} \mathrm{~K}_{120}^{120}+\mathrm{Mo}_{1.5}^{2.5}+\mathrm{Zn}_{2.5}$ & 4.0 & 1.62 & 0.60 & 0.32 & 4.69 & 3.55 & 0.69 & 0.45 \\
\hline
\end{tabular}


up better by plants, if there is nitrogen, due to synthesis of organophosphorus compounds $s^{5-6}$.

In the course of our trials application of phosphate fertilizers in combination with nitrogenpotassium fertilizers and micronutrients the content of ammonium carbonate-soluble phosphorus has sufficiently increased proportionally with fertilizers application rates. Thus, labile phosphorous content in the topsoil of the control variant amounted to $23.0 \mathrm{mg}$ at the initial stage, $24.2 \mathrm{mg} / \mathrm{kg}$ soil at milky-wax ripeness of corn and pod formation; on variants $\mathrm{N}_{60} \mathrm{P}_{60} \mathrm{~K}_{60}$ and $\mathrm{N}_{120} \mathrm{P}_{120} \mathrm{~K}_{120}$ with micronutrients it amounted to 30.5-31.6 mg at the stage of 5-6 leaves of corn and the third ternate leaf of soybean, and at milky-wax ripeness of corn and pod formation it amounted to $21.9-23.4 \mathrm{mg} / \mathrm{kg}$ soil respectively. Application of nitrogen fertilizers $\left(\mathrm{N}_{60}, \mathrm{~N}_{120}\right)$ before sowing and top-dressing of the corn and soybean mix promoted further increase of labile phosphorus in the soil (Table 2).

Labile phosphorus content in the soil at combination of $\mathrm{N}_{60} \mathrm{P}_{60} \mathrm{~K}_{60}$ and $\mathrm{N}_{120} \mathrm{P}_{120} \mathrm{~K}_{120}$ with microfertilizers amounted to $26.0 \mathrm{mg} / \mathrm{kg}$ and 26.9 $\mathrm{mg} / \mathrm{kg}$ versus $20.3 \mathrm{mg} / \mathrm{kg}$ soil on the control variant. On the mentioned variants quantity of labile phosphorus was sufficiently lower by the end of the vegetation stage as compared to its content in the soil at the initial stages, which is, probably, connected with its intensive consumption by the corn and soybean.

Along with nitrogen and phosphorus, potassium plays a big role in the mineral nutrition

Table 4. Accumulation $\backslash$ of the oven-dry biomass at the intercropping of corn with soybean (average within 2 years)

Variants Stages, cwt/ha

\begin{tabular}{ccc}
\hline 5-6 leaves of corn and the & $\begin{array}{c}\text { Heading of panicles } \\
\text { and blooming }\end{array}$ & $\begin{array}{c}\text { Milky-wax } \\
\text { ripeness of corn } \\
\text { and pod formation }\end{array}$
\end{tabular}

\begin{tabular}{llll}
\hline 1. Control & 50.1 & 124.8 & 170.4 \\
2. $\mathrm{N}_{60} \mathrm{P}_{60} \mathrm{~K}_{60}$ & 65.6 & 152.0 & 199.3 \\
3. $\mathrm{N}_{60} \mathrm{P}_{60} \mathrm{~K}_{60}+\mathrm{Mo}_{1.5}$ & 65.4 & 169.2 & 200.7 \\
4. $\mathrm{N}_{60} \mathrm{P}_{60} \mathrm{~K}_{60}+\mathrm{Zn}_{2.5}$ & 70.3 & 191.6 & 215.3 \\
5. $\mathrm{N}_{60} \mathrm{P}_{60} \mathrm{~K}_{60}+\mathrm{Mo}_{1.5}+\mathrm{Zn}_{2.5}$ & 69.9 & 211.0 & 219.4 \\
6. $\mathrm{N}_{120} \mathrm{P}_{120} \mathrm{~K}_{120}$ & 73.2 & 179.3 & 210.1 \\
7. $\mathrm{N}_{122} \mathrm{P}_{120} \mathrm{~K}_{120}+\mathrm{Mo}_{1.5}$ & 74.8 & 196.4 & 209.6 \\
8. $\mathrm{N}_{120} \mathrm{P}_{120} \mathrm{~K}_{120}+\mathrm{Zn}_{2.5}$ & 73.6 & 177.3 & 213.1 \\
9. $\mathrm{N}_{120} \mathrm{P}_{120} \mathrm{~K}_{120}+\mathrm{Mo}_{1.5}+\mathrm{Zn}_{2.5}$ & 95.9 & 175.8 & 205.9 \\
\hline
\end{tabular}

Table 5. The corn green structure at intercropping with soybean (average 2014-2015)

\begin{tabular}{|c|c|c|c|c|c|c|c|c|}
\hline \multirow[t]{2}{*}{ Variants } & \multicolumn{4}{|c|}{ Kernels } & \multirow{2}{*}{$\begin{array}{c}\text { Weight } \\
\text { of one } \\
\text { plant, g }\end{array}$} & \multicolumn{3}{|c|}{ Including } \\
\hline & $\begin{array}{c}\text { Rows } \\
\text { in the } \\
\text { corncob, } \\
\text { pcs }\end{array}$ & $\begin{array}{l}\text { Kernels } \\
\text { in the } \\
\text { row, pcs }\end{array}$ & $\begin{array}{l}\text { Kernels } \\
\text { in the } \\
\text { corncob, } \\
\text { pcs }\end{array}$ & $\begin{array}{c}\text { Kernel } \\
\text { weight } \\
\text { in the } \\
\text { corncob , g }\end{array}$ & & Leaves & Stalk & Corncobs \\
\hline 1. Control & 12.5 & 38 & 460 & 125.3 & 720 & 180 & 305 & 235 \\
\hline 2. $\mathrm{N}_{60} \mathrm{P}_{60} \mathrm{~K}_{60}$ & 13.0 & 41 & 502 & 135.1 & 1060 & 215 & 545 & 300 \\
\hline 3. $\mathrm{N}_{60} \mathrm{P}_{60} \mathrm{~K}_{60}+\mathrm{Mo}_{1.5}$ & 13.5 & 39 & 495 & 141.0 & 1335 & 294 & 706 & 335 \\
\hline 4. $\mathrm{N}_{60} \mathrm{P}_{60} \mathrm{~K}_{60}^{60}+\mathrm{Zn}_{2.5}$ & 14.0 & 43 & 565 & 145.2 & 1150 & 190 & 650 & 310 \\
\hline 5. $\mathrm{N}_{60} \mathrm{P}_{60} \mathrm{~K}_{60}+\mathrm{Mo}_{1.5}+\mathrm{Zn}_{2.5}$ & 14.5 & 45 & 588 & 145.9 & 1510 & 255 & 820 & 435 \\
\hline 6. $\mathrm{N}_{120} \mathrm{P}_{120} \mathrm{~K}_{120}$ & 13.5 & 42 & 481 & 143.5 & 1045 & 185 & 600 & 260 \\
\hline 7. $\mathrm{N}_{120} \mathrm{P}_{120} \mathrm{~K}_{120}+\mathrm{Mo}_{1.5}$ & 14.0 & 41 & 495 & 145.2 & 1035 & 220 & 590 & 225 \\
\hline 8. $\mathrm{N}_{120} \mathrm{P}_{120} \mathrm{~K}_{120}+\mathrm{Zn}_{2.5}$ & 14.5 & 46 & 590 & 146.8 & 1350 & 330 & 690 & 330 \\
\hline 9. $\mathrm{N}_{120} \mathrm{P}_{120} \mathrm{~K}_{120}+\mathrm{Mo}_{1.5}+\mathrm{Zn}_{2.5}$ & .515 .0 & 47 & 601 & 147.0 & 1660 & 325 & 860 & 475 \\
\hline
\end{tabular}


of the plants. It fulfills important functions in physiological and biological processes.

Potassium status of the plants is determined, first of all, by exchange potassium in the soil, the content of which depends on soil texture and mineral composition, humus content, soil medium reaction, fertilizers and other factors.
In the frame of our trials, exchange potassium in the meadow chestnut soil and its dynamics depended little on fertilizers as opposed to mineral nitrogen and labile phosphorus. We think that this may be due to, first of all, small norms (60 $\mathrm{kg} / \mathrm{ha}$ and $120 \mathrm{~kg} / \mathrm{ha} \mathrm{K}_{2} \mathrm{O}$ ) of applied potassium fertilizers, as well as their high content in the soil

Table 6. The soybean green structure at intercropping with corn (average 2014-2015)

\begin{tabular}{|c|c|c|c|c|c|}
\hline \multirow[t]{2}{*}{ Variants } & \multirow{2}{*}{$\begin{array}{l}\text { One plant } \\
\text { weight, g }\end{array}$} & \multicolumn{3}{|c|}{ Including } & \multirow{2}{*}{$\begin{array}{c}\text { Beans per one } \\
\text { plant, pcs }\end{array}$} \\
\hline & & Leaves & Stalk & Beans & \\
\hline 1. Control & 49.8 & 14.8 & 21.5 & 13.8 & 21 \\
\hline 2. $\mathrm{N}_{60} \mathrm{P}_{60} \mathrm{~K}_{60}$ & 51.5 & 15.6 & 21.6 & 14.3 & 27 \\
\hline 3. $\mathrm{N}_{60} \mathrm{P}_{60} \mathrm{~K}_{60}^{60}+\mathrm{Mo}_{1.5}$ & 63.9 & 17.5 & 31.3 & 15.1 & 30 \\
\hline 4. $\mathrm{N}_{60}^{60} \mathrm{P}_{60} \mathrm{~K}_{60}^{60}+\mathrm{Zn}_{2.5}^{1.5}$ & 60.7 & 16.0 & 29.9 & 14.8 & 28 \\
\hline 5. $\mathrm{N}_{60} \mathrm{P}_{60} \mathrm{~K}_{60}+\mathrm{Mo}_{1.5}+\mathrm{Zn}_{2.5}$ & 67.8 & 18.9 & 34.4 & 14.5 & 31 \\
\hline 6. $\mathrm{N}_{120} \mathrm{P}_{120} \mathrm{~K}_{120}$ & 63.0 & 15.2 & 33.3 & 14.5 & 25 \\
\hline 7. $\mathrm{N}_{120} \mathrm{P}_{120} \mathrm{~K}_{120}+\mathrm{Mo}_{1.5}$ & 64.7 & 17.8 & 31.7 & 15.2 & 28 \\
\hline 8. $\mathrm{N}_{120} \mathrm{P}_{120} \mathrm{~K}_{120}+\mathrm{Zn}_{2.5}$ & 58.9 & 15.1 & 29.8 & 14.0 & 24 \\
\hline 9. $\mathrm{N}_{120} \mathrm{P}_{120} \mathrm{~K}_{120}+\mathrm{Mo}_{1.5}^{2.5}+\mathrm{Zn}_{2.5}$ & 68.1 & 17.8 & 35.1 & 15.2 & 30 \\
\hline
\end{tabular}

Table 7. Yield of the corn and soybean mix depending on fertilizers applied, cwt/ha

\begin{tabular}{|c|c|c|c|c|c|}
\hline \multirow[t]{2}{*}{ Variants } & \multicolumn{3}{|c|}{ Green mass yield, cwt/ha } & \multicolumn{2}{|c|}{ Yield growth, \% } \\
\hline & 2014 & 2015 & Average within 2 years & cwt/ha & $\%$ \\
\hline 1. Control & 504.3 & 525.8 & 515.0 & - & - \\
\hline 2. $\mathrm{N}_{60} \mathrm{P}_{60} \mathrm{~K}_{60}$ & 584.7 & 654.1 & 619.4 & 104.4 & 20.2 \\
\hline 3. $\mathrm{N}_{60} \mathrm{P}_{60} \mathrm{~K}_{60}+\mathrm{Mo}_{1.5}$ & 632.5 & 725.9 & 679.2 & 164.2 & 31.8 \\
\hline 4. $\mathrm{N}_{60} \mathrm{P}_{60} \mathrm{~K}_{60}+\mathrm{Zn}_{2.5}$ & 690.8 & 710.5 & 700.6 & 185.6 & 36.0 \\
\hline 5. $\mathrm{N}_{60} \mathrm{P}_{60} \mathrm{~K}_{60}+\mathrm{Mo}_{1.5}+\mathrm{Zn}_{2.5}$ & 730.8 & 820.1 & 775.4 & 260.4 & 50.5 \\
\hline 6. $\mathrm{N}_{120} \mathrm{P}_{120} \mathrm{~K}_{120}$ & 700.0 & 687.4 & 693.7 & 178.7 & 34.6 \\
\hline 7. $\mathrm{N}_{120} \mathrm{P}_{120} \mathrm{~K}_{120}+\mathrm{Mo}_{1.5}$ & 695.8 & 736.8 & 716.3 & 201.3 & 39.0 \\
\hline 8. $\mathrm{N}_{120} \mathrm{P}_{120} \mathrm{~K}_{120}+\mathrm{Zn}_{2.5}$ & 702.7 & 754.6 & 728.6 & 213.6 & 41.4 \\
\hline 9. $\mathrm{N}_{120} \mathrm{P}_{120} \mathrm{~K}_{120}+\mathrm{Mo}_{1.5}+\mathrm{Zn}_{2.5}$ & 721.3 & 795.1 & 758.2 & 243.2 & 47.2 \\
\hline
\end{tabular}

Table 8. Influence of fertilizers on feeding quality of the green mass of the corn and soybean mix, \% per oven-dry matter (average 2014-2015)

\begin{tabular}{|c|c|c|c|c|c|c|c|}
\hline No. & Variants & Crude protein & Oil & Free-nitrogen extract & Fibre & Ash & $\mathrm{Ca}$ \\
\hline 1. & Control & 7.25 & 0.9 & 40.1 & 29.0 & 5.4 & 0.29 \\
\hline 2. & $\mathrm{~N}_{60} \mathrm{P}_{60} \mathrm{~K}_{60}$ & 9.68 & 1.1 & 45.6 & 25.5 & 6.9 & 0.35 \\
\hline 3. & $\mathrm{~N}_{60} \mathrm{P}_{60} \mathrm{~K}_{60}+\mathrm{Mo}_{1.5}$ & 10.0 & 1.6 & 43.6 & 29.6 & 7.5 & 0.39 \\
\hline 4. & $\mathrm{~N}_{60} \mathrm{P}_{60} \mathrm{~K}_{60}+\mathrm{Zn}_{2.5}$ & 7.87 & 1.5 & 47.8 & 30.1 & 6.5 & 0.37 \\
\hline 5. & $\mathrm{~N}_{60} \mathrm{P}_{60} \mathrm{~K}_{60}+\mathrm{Mo}_{1.5}+\mathrm{Zn}_{2.5}$ & 8.5 & 1.8 & 48.4 & 30.1 & 6.9 & 0.41 \\
\hline 6. & $\mathrm{~N}_{120} \mathrm{P}_{120} \mathrm{~K}_{120}$ & 10.0 & 1.6 & 50.0 & 29.1 & 7.0 & 0.40 \\
\hline 7. & $\mathrm{~N}_{120} \mathrm{P}_{120} \mathrm{~K}_{120}+\mathrm{Mo}_{1.5}$ & 9.06 & 1.7 & 49.2 & 28.8 & 7.2 & 0.42 \\
\hline 8. & $\mathrm{~N}_{120} \mathrm{P}_{120} \mathrm{~K}_{120}+\mathrm{Zn}_{2.5}$ & 9.37 & 1.6 & 49.9 & 29.9 & 6.9 & 0.42 \\
\hline 9. & $\mathrm{~N}_{120} \mathrm{P}_{120} \mathrm{~K}_{120}+\mathrm{Mo}_{1.5}+\mathrm{Zn}_{2.5}$ & 10.1 & 2.0 & 50.1 & 31.3 & 7.9 & 0.41 \\
\hline
\end{tabular}


under survey.

Chemical composition of plants is an important characteristic determining availability of mineral elements to them. Nutritional conditions exercise significant influence over nitrogen and phosphorus content in vegetative mass of corn and soybean. On the variants with and without fertilizers one may see differences in chemical composition of the plants, especially corn, at the initial stages of growth, which remain till the vegetation end. At the harvesting stage on the fertilized variants nitrogen content in the corn amounted to $1.26-1.62 \%$, phosphorus $-0.26-0.32 \%$, and on the control variant $-1.16 \% \mathrm{~N}$ and $0.21 \% \mathrm{P}$ respectively. Under effect of macro- and microfertilizers nitrogen, content in soybean increased from 2.32 to $3.66 \%$, phosphorus - from 0.32 to $0.48 \%$, and on the control variant $-0.30 \%$ (Table 3).

Table 4 shows that at the initial stage (56 leaves of corn, the third ternate leaf of soybean) nitrogen content in the plant varied from $1.7 \%$ to 2.6-3.4\%, and in the soybean - from $2.9 \%$ to 3.06 $4.69 \%$ on the fertilized variants. Corn and soybean nitrogen content decreased at the ripeness stage comparing to the initial one. At the vegetation stage, the activity of the photosynthetic and symbiotic apparatus decreases, and due to outflow to the caryopsis nitrogen concentration drops in vegetative organs as compared to the previous stages of growth. Maximum nitrogen content in the corn was on the variant $\mathrm{N}_{120} \mathrm{P}_{120} \mathrm{~K}_{120}$ with application of micronutrients $\left(\mathrm{Mo}_{1.5}+\mathrm{Zn}_{2.5}\right)$, and in the soybean $-\mathrm{N}_{60} \mathrm{P}_{60} \mathrm{~K}_{60}$ with zinc and molybdenum. Maximum phosphorus content in the corn and soybean plants was on the variant $\mathrm{N}_{60} \mathrm{P}_{60} \mathrm{~K}_{60}+\mathrm{Mo}_{1.5}+\mathrm{Zn}_{2.5}$. During the soybean vegetation stage NP content in the plant increased on all variants, but it was the most significant at application of Mo and $\mathrm{Zn}$ rated dose.

Dry matter and yield, first of all, were determined by productivity of the photosynthetic apparatus. Many factors, conditions of mineral nutrition inclusive, influence the photosynthetic crops activity ${ }^{6}$.

This point is proved by our investigations (Table 4). Determination of the crop dry matter showed that its quantity increases sufficiently at fertilizer treatment. In Table 4 you may see that fertilizing positively influenced accumulation of the biomass of the crop under survey. From the earliest vegetation stages it was more active on the fertilized variants than on the control one (without fertilizers). Thus, the corn and soybean dry matter, equal at the control variant, had the following figures by stages: 5-6 leaves of corn and the third ternate leaf of soybean - $50.1 \mathrm{cwt} / \mathrm{ha}$, heading of panicles and blooming $-124.8 \mathrm{cwt} / \mathrm{ha}$, milky-wax ripeness of corn and pod formation $-170.4 \mathrm{cwt} / \mathrm{ha}$. On the fertilized variants it varied from 65.4 to $74.8 \mathrm{cwt} / \mathrm{ha}, 152.0$ to $211.0 \mathrm{cwt} / \mathrm{ha}, 199.3$ to $219.4 \mathrm{cwt} / \mathrm{ha}$ respectively.

Yield and quality of the green mass were mainly determined by formation of structural elements constituting the yield. Stalks (42-52\% of total weight) and corncobs (28-32\%) prevail in the corn green mass, while leaves (48-51\%) and stalks (26-29\%) prevail in the soybean green. We think that low number of corn leaves and soya beans in their green mass is due to the cross effect of the corn and soybean at combined growth. Thus, at intercropping the soybean provided for early fading of corn leaves, and height of the corn shadowed the soybean and negatively influenced formation of its reproductive organs (beans) (Table 5).

After application of fertilizers corn and soybean yield increased mainly resulting in growth of corncobs and beans weight, their number, stalks and leaves weight. Thus, corncobs yield was influenced by increasing norms of nitrogen fertilizers, as well as micronutrients combined with mineral fertilizers $\mathrm{N}_{120} \mathrm{P}_{120} \mathrm{~K}_{120}$. On the marked variants corncobs weight increased from $235 \mathrm{~g}$ (control) to 225-475 g, stalk weight - from $305 \mathrm{~g}$ to 545-860 g, and leaves weight - from $180 \mathrm{~g}$ to 215$325 \mathrm{~g}$. The most soybeans (32 pcs) were found on the variant $\mathrm{N}_{60} \mathrm{P}_{60} \mathrm{~K}_{60}+\mathrm{Mo}_{1.5}+\mathrm{Zn}_{2.5}$. Formation of the structural elements of the soybean green mass was positively influenced by combination of microfertilizers with moderate norms of mineral fertilizers $\mathrm{N}_{60} \mathrm{P}_{60} \mathrm{~K}_{60}$ (Table 6).

In order to increase crop yield it is important to optimize mineral nutrition of the plants with all essential macro- and microelements. Fertilizers hold a specific place in the system of yield increasing activities? ${ }^{7}$.

Yield of the corn and soybean mix is the main criteria for assessing fertilizers under survey at the corn and soybean production. Effect of NPK and micronutrients estimated norms on corn and soybean yield is shown in Table 7. 
On the unfertilized variant total silage amounted to $515.0 \mathrm{cwt} / \mathrm{ha}$ (average within 2 years). On the fertilized variants silage amounted to 619.4$775.4 \mathrm{cwt} / \mathrm{ha}$, growth due to fertilizers was 104.4$260.4 \mathrm{cwt} / \mathrm{ha}$. The highest feed yield (average within 2 years $775.4 \mathrm{cwt} / \mathrm{ha}$ ) was achieved at combined application of microfertilizers with $\mathrm{N}_{60} \mathrm{P}_{60} \mathrm{~K}_{60}$. Table 6 shows high efficiency of mineral fertilizers with separately applied microfertilizers at intercropping of corn with soybean. Application of macrofertilizers with separately introduced microfertilizers resulted in total green mass yield growth within 164.2-213.6 cwt/ha versus the control. In some variants, where only mineral fertilizers were applied, silage yield amounted to 619.4-693.7 cwt/ha (average within 2 years).

It is highly important to determine changes in silage feeding quality (content of protein, oil, calcium, ash, fibre, free-nitrogen extract) at intercropping of corn with soybean at fertilizing (Table 8).

Crude protein content in the corn in the period of milky-wax ripeness varies from 6.0 to $8.0 \%$ without fertilizers and from 9.0 to $11.0 \%$ with fertilizers depending on cultivation conditions [8]. Under conditions of our trials at intercropping of corn with soybean protein content in the feed mass increased up to $7.25 \%$ on the control variant and up to $7.87-10.1 \%$ on the fertilized variants.

It should be noted that at cultivation of corn with soybean content of oil, ash, calcium and other components increases sufficiently, if fertilizers are applied ${ }^{9-10}$. Table 7 shows that fertilizers raise percentage of ash and calcium in the green mass of the corn and soybean mix. Due to fertilizers ash content went up by $1.1-2.5 \%$, protein $-1.81-2.85 \%$, calcium $-0.06-0.12 \%$ as compared to the control (average within 2 years). Besides, fibre and free-nitrogen extract content in silage with different fertilizer systems increased.

At low oil content in the feed mass mineral fertilizers had some effect as compared to the organic ones. Thus, oil content on the variants with macro- and microfertilizers varied from 1.1$2.0 \%$ versus $0.9 \%$ on the control variant.

\section{CONCLUSIONS}

Application of macrofertilizers both separately and in combination with micronutrients promoted an increase of nitrogen and phosphorus content in the corn and soybean plants, and the yield itself as compared to the control (without fertilizers).

Under conditions of the piedmont irrigated meadow chestnut soil in southeastern Kazakhstan high productivity of the corn and soybean mix with good feed characteristics is provided due to combined application of $\mathrm{N}_{60} \mathrm{P}_{60} \mathrm{~K}_{60}$ with microfertilizers Mo and Zn.

Application of different fertilizer systems at intercropping of corn with soybean promotes an increase of protein by $1.81-2.85 \%$, oil $-0.2-1.1 \%$, ash $-1.1-2.5 \%$ and calcium $-0.06-0.12 \%$ in the green mass.

\section{REFERENCES}

1. Adaptive Oil Crops Cultivation Technologies in the Southern Region, Krasnodar, 2010.

2. Lukomets, V.M. (Ed.), Methods of Conducting Field Trials with Oil Crops. Krasnodar, 2010.

3. Tersich, D., M.S. Tosic, B. Dinic, D. Lazarevich and J. Radovich, Archive of Agricultural Sciences, 2001; 62: 151-158.

4. Sheudzhen, A.K., T.N. Bondareva and L.V. Onishchenko, Grain, Cereal and Pulse Crops Feeding and Fertilizing. Krasnodar: Kuban State Agrarian University, 2012.

5. Kovda, V.A., Micronutrients in the Soils of the Soviet Union. Moscow: MSU Publishing House, 1973.

6. Alves, J.R., L. Zotarelli, F.M. Fernandes, J.C. Heckler, R.A.T. Macedo, R.M. Boddey, C.P. Jantalia and S. Urquiaga, Biological Nitrogen Fixation and Nitrogen Fertilizer on the Nitrogen Balance of Soybean, Maize and Cotton. Pesquisa Agropecuária Brasileira, 2006; 41: 449-456.

7. Buldykova, I.A., Role of Micronutrients in Increasing Corn Yield and Quality. Enthusiasts of Agrarian Science, 2010; 12: 84-86.

8. Carruthers, K., B. Prithiviraj, Q. Fe, D. Cloutier, R.C. Martin and D.L. Smith, Intercropping of Corn with Soybean, Lupin and Forages: Silage Yield and Quality. Journal of Agronomy and Crop Science, 2000; 185(3): 177-185.

9. Siritsa, A.I., Influence of Mineral Fertilizers on Corn Yield, Ph.D. Thesis Abstract, Alma-Ata, 1965.

10. Zhailybayev, K.N., Intercropping of Corn with Soybean. Alma-Ata: Kainar, 1981. 